\title{
BLISS'S RULE AND OLD ENGLISH METRICS
}

Old English poetry is characterized by its varying and unpredictable number of syllables per verse. In Beowulf, ${ }^{1}$ for example, tetrasyllabic verses like 1. 42a, on flōdes $\overline{\alpha e} h t$, are very frequent, but one can also find verses like 1. 1189b, ond hoelepa bearn, and 1. 1954b, wið haelepa brego, which respectively consist of five and six syllables. This peculiar feature puzzled early scholars of Old English poetry, who found themselves unable to come up with a coherent explanation for such a bewildering array of syllabic sequences. At the end of the nineteenth century, however, Eduard Sievers managed to make sense of the disconcerting evidence furnished by Old English poetic texts. ${ }^{2}$ Based on the preponderance of four-syllable verses, Sievers posited the existence of a four-position metrical template that is able to accommodate all the verses equally, regardless of their number of syllables. The adjustment of verses of more than four syllables to this fourposition pattern, he argued, is enacted by a process of syllabic equivalence known as "resolution" (Auflösung in Sievers's original terminology). The operation of resolution renders a light stressed syllable and its unstressed successor metrically equivalent to a single heavy stressed syllable. ${ }^{3}$ The disyllabic sequences hoele- and brego in $1189 \mathrm{~b}$ and 1954b undergo resolution, thereby occupying one metrical position each, and so ond haelepa bearn and wið halepa brego possess the same four-position configuration as on

\footnotetext{
${ }^{1}$ Cited from Fulk et al.

${ }^{2}$ See Sievers, "Zur Rhythmik"; Altgermanische Metrik.

${ }^{3}$ A syllable is light if it ends in a short vowel. If it ends either in a long vowel or in vowel (long or short) followed by a consonant, that syllable is heavy. In Old English, the syllable boundary precedes a lone intervocalic consonant. The initial syllables of haelepa (ho-) and brego (bre-) are therefore light, while the initial syllable of flōdes (flō-) is heavy. See, for example, Bliss, Introduction (9).
} 
flödes $\bar{x} h t .{ }^{4}$ Sievers's fundamental assumption that all the verses, irrespective of how many syllables they contain, consist of exactly four positions thus shed considerable light on the workings of Old English versification. ${ }^{5}$

Sievers's four-position principle accounts for such an impressive number of halflines that many scholars consider that the few verses that fail to comply with that principle must have been tampered with by scribes, even if there is nothing wrong with those verses in terms of grammar, sense, or alliteration. Take Beowulf 25a, in mōè $b a$ gehwōere, for example. Its meaning, "in every nation," perfectly suits the universalizing comment of which it is part ("from praiseworthy deeds comes success in every nation"); ${ }^{6}$ its alliterative patterning and grammar are unquestionable ${ }^{7}$ and its legibility has not been affected in the course of textual transmission. This verse is nonetheless considered by many to be inauthentic because it consists of a sequence of six syllables that is not reducible to a four-position scheme (both its stressed syllables, mōe $\dot{g}-$ and $-h w \overline{\alpha^{-}}$, are heavy and hence cannot undergo resolution with $-p a$ and $-r e$, respectively). ${ }^{8}$ These scholars believe that the original verse must have actually read in mōe $\dot{g} p a \dot{g} e h w \bar{e} m$, a four-

\footnotetext{
${ }^{4}$ These are all type B verses, with a rising-rising metrical contour (x / x /). For a dependable introduction to the basics of Old English versification, see Terasawa.

${ }^{5}$ The four-position principle is also enacted by the principle of drop protraction, according to which several unstressed syllables count as a single metrical position as long as they are all adjacent to each other.

${ }^{6}$ This translation is by Fulk, The Beowulf Manuscript (87).

${ }^{7}$ Alliteration is on $m$ (the off-verse is man gepên). The feminine singular pronoun $\dot{g}$ ehwäre, in the dative case as demanded by the preposition in, agrees in gender with the plural noun it governs, māe $\dot{g} p a$, a partitive genitive.
}

${ }^{8}$ For a more detailed discussion of this verse, see Fulk et al. (328). 
position half-line identical in structure to on flodes $\bar{x} h t,{ }^{9}$ and that a scribe insensitive to the four-position rule substituted the analogical Late West Saxon feminine form gehwēre for the older genderless gehwöm, thereby spoiling the metre. ${ }^{10}$ In fact, this analysis derives additional support from verses like Beowulf 1365a, Dōer moè nihta gehwäm, and

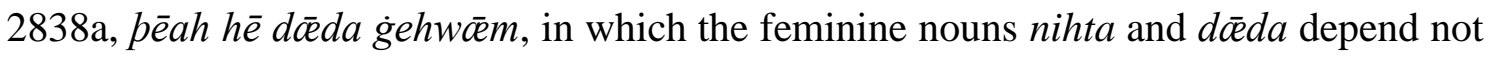
on $\dot{g} e h w a \bar{e} r e$, but on $\dot{g} e h w \bar{e} m$.

Despite the enormous explanatory power of the four-position principle, and in spite of the additional support that can usually be found for analysing non-four-position verses as inauthentic, ${ }^{11}$ modern editors of Old English verse texts remain reluctant to emend manuscript readings on the sole basis of metre. This reluctance is perhaps grounded in the non-survival of an Anglo-Saxon ars poetica or metrical treatise, which makes it impossible to check Sievers's observations against the opinions of native informants. As Norman Blake put it in an essay on the dating of Old English poetry:

We should not forget that we know nothing about the Anglo-Saxons' attitude towards English alliterative style or metre. We cannot tell whether they regarded things in the same light as we do or what movements of style motivated their approach. We may think that the style of The Battle of Maldon is decadent and so base our dating on that view — but there is no evidence that they saw the poem in this way. Their understanding of metre is also something that eludes us. We can try to decide when they used hypermetric lines, for example, but we cannot tell whether people then approved of them or not. (Blake 15-16)

Belief in the futility of metrical studies has resulted in a conservative approach to the editing of Old English poetic manuscripts. In the absence of errors of a nature other than

\footnotetext{
${ }^{9}$ Both are type B verses. The two unstressed syllables - $p a$ and $\dot{g} e$ - occupy a single position because of drop protraction (see note 5 above).

${ }^{10}$ See, for example, Fulk et al. (114); Neidorf, The Transmission of Beowulf (36-37).

${ }^{11}$ For examples, see Pascual, “Three-position Verses”; "Manuscript Evidence.”
} 
metrical, editors would rather retain an aberrant non-four-position verse than emend it, on the assumption that scribal practice is more reliable than modern Sieversian metrics. As E.G. Stanley memorably stated:

...we in our subject have to remember with constant humility that though perhaps, not certainly, most scribes may not have been the equals in Old English of the best Old English poets, every one of them, sleepy and careless as he may have been at times, knew his living Old English better than the best modern editor of Old English verse. (Stanley 257)

Since Stanley's conservative policy has won the day among editors, it is unsurprising that the majority of editions of Beowulf preserve manuscript readings like in mōg $\dot{g} b a \dot{g} e h w \overline{c e} r e$, thus disregarding the conclusions of Sieversian metrical scholarship.

Is this distrust of Sievers's metrical model justified? As R.D. Fulk and others have contended, there are good reasons to believe that Sievers's theory is essentially correct, and that it can therefore be relied upon for the editing and textual criticism of Old English verse. ${ }^{12}$ In this note, I contribute to these scholars' argumentation by working out the implications of Bliss's rule of auxiliary verbs for Old English metrics, which have so far gone unnoticed. In an important essay published in 1981, A.J. Bliss observed that in Beowulf finite auxiliary verbs present different distributional patterns depending on their phonological structure. ${ }^{13}$ Phonologically light auxiliaries, which consist either of a heavy stressed syllable, like bip, moeg, or sceal, or of a light stressed syllable plus another, like hafast, hafap, sculon, or scyle, always appear in the first half-line of a verse clause,

\footnotetext{
${ }^{12}$ See, for instance, Cable; Fulk, "Early Middle English Evidence"; Neidorf, "Metrical Criteria." Support for the essential correctness of Sieversian metrics can also be derived from Daniel Donoghue's conclusion that Kuhn's first law, which is based on Sievers's scansion, is really at work in Old English verse. See Donoghue, "Language Matters."

${ }^{13}$ See Bliss, "Auxiliary and Verbal" (160-162). Donoghue subsequently demonstrated that Bliss's rule obtains in a broad selection of classical Old English poems. See Donoghue, Style in Old English Poetry.
} 
regardless of whether they receive ictus or not, and also regardless of whether they occupy one or two metrical positions, as the following examples from Beowulf illustrate (auxiliaries are italicized):

\section{$\bar{a} m o \dot{g}$ God wyrćan}

wunder æfter wundre, wuldres hyrde. (930b-931b)

Hafast pū gefēred pæt ðē feor ond nēah

ealne wīdeferhp weras ehtigiað (1221a-1222b)

Ic் ðæs ealles móg

feorhbennum sēoc ġefēan habban. (2739b-2740b)

hwæt mē Grendel hafað

hȳnðo on Heorote mid his hetepancum (474b-475b)

Nū scealc hafað

purh drihnes miht dǣd gefremede (939b-940b)

As can be seen, if an auxiliary is phonologically light, then it is exclusively located, irrespective of its metrical behaviour, in the first half-line of its clause. ${ }^{14}$ If, on the other hand, a finite auxiliary verb is heavy (that is, if it consists of a heavy stressed syllable followed by another, like scolde or hafde), ${ }^{15}$ then it is unrestricted in regard to its location within the clause, and can appear in any of that clause's constituent verses:

Scolde his aldọrgedāl

\footnotetext{
${ }^{14}$ In $930 \mathrm{~b}$ and 1221a, the auxiliary is non-ictic; in 2739b, monosyllabic moeg receives ictus; disyllabic hafað in 474 receives ictus and undergoes resolution, thereby occupying the second lift of a type B verse; in 939b, resolution of hafað is regularly suspended after a monosyllabic lift (scealc), so that ha-receives ictus and fað does not.

15 The terms "light" and "heavy" as applied to finite auxiliaries were coined by Donoghue in his detailed study of Bliss's rule. See Donoghue, Style in Old English Poetry (9-10). Bliss used the less precise "monosyllabic" and "disyllabic."
} 
on ðǣm dæg்e pysses līfes

earmlic wurðan (805b-807a)

oð pæt him ǣg̈hwylć ymbsittendra

ofer hronrāde hȳran scolde. ${ }^{16} \quad(9 \mathrm{a}-10 \mathrm{~b})$

In the first example, the heavy auxiliary scolde appears in the first verse of a four-halfline clause; while in the second, it is placed in the last of a four-half-line clause. ${ }^{17}$

The significance of Bliss's rule in the present context is that it is predicated on the same process of syllabic equivalence as Sievers's four-position principle. Just as disyllables like hale- and brego correspond to heavy monosyllables in Sievers's analysis, disyllabic auxiliaries like scyle and hafap are, according to Bliss's, equivalent to monosyllables like sceal and moeg, not to disyllables like scolde and hafde. That these two rules are enacted by the same sort of syllabic equivalence is especially remarkable because they are each independent of the other. The domain of Bliss's rule is the verse clause, understood as the smallest series of half-lines that can express a complete grammatical proposition, whereas Sievers's principle is exclusively concerned with the internal structure of half-lines. Consequently, as seen above, the metrical values that light auxiliaries are accorded by Sieversian scansion within a given half-line are irrelevant to the clausal location that Bliss's rule dictates for such auxiliaries. In fact, Bliss could have formulated his syntactic rule of auxiliary verbs even if Sievers's theory of metre had never

\footnotetext{
${ }^{16}$ In $805 \mathrm{~b}$, scolde is non-ictic and so it is part of the initial drop of a type B verse. In $10 \mathrm{~b}$, it is ictic and hence occupies the second lift of a type A. In my citation of $1.9 \mathrm{~b}$, I have not included the interpolated demonstrative pāra, which is underdotted in Fulk et al.

${ }^{17}$ The implications of Bliss's rule for the understanding of how Old English verse texts were read by AngloSaxon audiences have been brilliantly worked out by Donoghue, How the Anglo-Saxons Read Their Poems (92-94).
} 
seen the light of day, because the half-lines of Old English poetry can be isolated with the sole guide of alliteration, without recourse to metrical analysis. ${ }^{18}$ That resolution can be independently observed in a syntactic context that is unrelated to Sievers's four-position framework can only mean that resolution is not a scholarly convenience of Sievers's system of scansion, but a real entity of Old English. Bliss's rule thus joins the Germanic minimal word restriction, the prosody of Icelandic rimur and Poema morale, and Kaluza's law as evidence for the authenticity of resolution. ${ }^{19}$

The demonstrable reality of resolution has important implications for Old English metrics. Resolution is not just a minor detail of Sievers's analysis, but the cornerstone of his theory. The minimum requirement for each verse to comprise no more and no less than four metrical positions could not be satisfied without resolution, which accommodates the syllables in a verse, irrespective of their number, into the basic four-

\footnotetext{
${ }^{18}$ This is generally true, but there are some exceptions. See Fulk, "On Argumentation" (12).

${ }^{19}$ The minimal word restriction refers to the early Germanic stricture against short vowels in stressed monosyllables, which were lengthened (e.g. $n u>n \bar{u}$ ). Because of the anomalous status of short stressed monosyllables, a word-internal stressed syllable ending in a short vowel was also perceived as anomalous, and hence that syllable absorbed into it the following unstressed syllable, thereby giving rise to a single prosodic unit consisting of a short stressed syllable plus another. Resolution is thus observable in the phonology of early Germanic. Resolution can also be independently observed in Icelandic rímur and the early Middle English Poema morale, both of which use prosodic systems unrelated to Old English versification. Kaluza's law refers to a regularity of the metre of Beowulf, according to which resolution under secondary stress obtains only if the inflectional ending involved is an etymologically short vowel (if the ending is an etymologically long vowel or contains a final consonant, resolution is suspended). The correlation between the operation of resolution and its suspension, on the one hand, and short and long endings, on the other, likewise demonstrates resolution to be genuine, since etymological length is a reality independent of Sievers's system of scansion. These pieces of evidence are analysed in detail in Fulk, "Early Middle English Evidence."
} 
position scheme. The regular operation of the four-position principle thus entirely depends on the policing role performed by resolution, the existence of which Sievers in turn hypothesised only to preserve the integrity of that principle. Both phenomena, resolution and the four-position principle, are therefore inextricably interconnected and mutually interdependent in Sieversian metrics. As a result, if resolution is a real entity, as the evidence furnished by Bliss's rule demonstrates, then Sievers's four-position analysis must likewise be real. Old English metre is not as elusive as critics like Blake maintained. The four-position theory captures a fundamental reality of Old English versification, and so the impossibility of contrasting the tenets of Sieversian metrics with an Anglo-Saxon ars poetica should not discourage modern editors of Old English poetic texts from confidently emending aberrant verses like in mōe $\dot{g} h a$ gehwēre to their likely original fourposition forms.

\section{WORKS CITED}

Blake, Norman. "The Dating of Old English Poetry." An English Miscellany Presented to W. S. Mackie, edited by Brian Lee, Oxford UP, 1977, pp. 14-27.

Bliss, Alan. Introduction to Old English Metre. Blackwell, 1962.

Bliss, Alan. "Auxiliary and Verbal in Beowulf." Anglo-Saxon England, vol. 9, 1981, pp. 157-182.

Cable, Thomas. The Meter and Melody of Beowulf. U of Illinois Press, 1974.

Donoghue, Daniel. Style in Old English Poetry: The Test of the Auxiliary. Yale UP, 1987.

Donoghue, Daniel. “Language Matters.” Reading Old English Texts, edited by Katherine O’Brien O’Keeffe, Cambridge UP, 1997, pp. 59-78.

Donoghue, Daniel. How the Anglo-Saxons Read Their Poems. U of Pennsylvania Press, 2018. 
Fulk, R.D. "Early Middle English Evidence for Old English Metrics: Resolution in Poema Morale.” Journal of Germanic Linguistics, vol. 14, 2002, pp. 331-355.

Fulk, R.D. “On Argumentation in Old English Philology.” Anglo-Saxon England, vol. 32, 2003, pp. 1-26.

Fulk, R.D., et al., eds. Klaeber's Beowulf. $4^{\text {th }}$ ed., Toronto UP, 2008.

Fulk, R.D., ed. and trans. The Beowulf Manuscript. Harvard UP, 2010.

Neidorf, Leonard. "Metrical Criteria for the Emendation of Old English Poetic Texts." Old English Philology: Studies in Honour of R.D. Fulk, edited by Leonard Neidorf, et al., D.S. Brewer, 2016, pp. 52-68.

Neidorf, Leonard. The Transmission of Beowulf: Language, Culture, and Scribal Behaviour. Cornell UP, 2017.

Pascual, Rafael J. "Three-position Verses and the Metrical Practice of the Beowulf Poet." SELIM (Journal of the Spanish Association for Medieval English Language and Literature $=$ Revista de la Sociedad Española de Lengua y Literatura Inglesa Medieval), vol. 20, 2013-2014, pp. 49-79.

Pascual, Rafael J. "Manuscript Evidence and Metrical Authenticity: A Response to Seiichi Suzuki.” Journal of Germanic Linguistics, vol. 29, 2017, pp. 85-99.

Sievers, Eduard. "Zur Rhythmik des germanischen Alliterationsverses.” Beiträge zur Geschichte der deutschen Sprache und Literatur, vol. 10, 1885, pp. 209-314, 451545.

Sievers, Eduard. Altgermanische Metrik. Max Niemeyer, 1893.

Stanley, E.G. "Unideal Principles of Editing Old English Verse." Proceedings of the British Academy, vol. 70, 1984, 231-273.

Terasawa, Jun. Old English Metre: An Introduction. U of Toronto Press, 2011. 